
\title{
25 Research Square \\ Climate Scenarios And Your Changes In The Life Zone For Brazil
}

\section{Rafael Fausto de Lima}

IFMS - Federal Institute of Education

LUCAS Eduardo OLIVEIRA-APARECIDO ( $\nabla$ ledoap@gmail.com )

Universidade de Sao Paulo https://orcid.org/0000-0002-4561-6760

João Antonio Lorençone

IFMS - Federal Institute of Education

Pedro Antonio Lorençone

IFMS - Federal Institute of Education

José Reinaldo da Silva Cabral de Moraes

IFMS - Federal Institute of Education

Kamila Cunha de Meneses

IFMS - Federal Institute of Education

\section{Research Article}

Keywords: Bioclimate, Climatic classification, IPCC, Agrometeorology

Posted Date: August 26th, 2021

DOl: https://doi.org/10.21203/rs.3.rs-643200/v1

License: (c) (i) This work is licensed under a Creative Commons Attribution 4.0 International License.

Read Full License 


\section{Abstract}

Climate classification systems are tools capable of facilitating the analysis, grouping, delimitation, and dissemination of climatic characteristics of a region, contributing to the delimitation of areas of fitness in the agricultural sector and validation of various models of climate change. Thus, we seek to determine life zones for Brazil using the ecological classification of Holdridge (1967) in different scenarios of climate change. A 30-year historical series (1989-2019) of climatic data of average air temperature $\left({ }^{\circ} \mathrm{C}\right)$ and rainfall $(\mathrm{mm})$ was used for the entire Brazilian territory, obtained through the National Aeronautics and Space Administration / Prediction of World platform Wide Energy Resources - (NASA/POWER). Potential evapotranspiration (PET) was estimated by the method of Camargo (1971) using combinations between annual precipitation, average annual biotemperature, average annual basal biotemperature, and the relationship between evapotranspiration and altitude, the life zones for the Holdridge (1967) system were defined. The scenarios used were based on the IPCC (2014) projections. The average temperature in Brazil ranges from 13.1 to $28.0^{\circ} \mathrm{C}$ and the average annual precipitation is 1467 ( \pm 46.91$) \mathrm{mm}$. In the current scenario for the classification of Holdridge (1967) the predominant zone of life is the humid basal tropical forest in $60.57 \%$ of the territory. The increase in temperature causes a predominance of the living zones Basal tropical rainforest in $48.92 \%$ for S2 and Basal tropical rainforest in $48.95 \%$ in S3, the reduction in precipitation $\mathrm{S} 4$ generates the predominance of the living zone Basal tropical forest drought in $49.87 \%$, with the increase in precipitation $\mathrm{S} 5$ there is a predominance of the zone of life Low humid basal tropical forest in $50.12 \%$ of the territory. The great variability of the obtained life zones makes the Holdridge system a useful tool to validate climate change scenarios.

\section{Introduction}

Climate change has become a major challenge for contemporary society (Herman et al. 2020). The global mean temperature of the air on the surface has increased steadily since the $1950 \mathrm{~s}$, in the last century, it increased by $1^{\circ} \mathrm{C}( \pm 0.2)$. The forecasts for 2100 are for increases between $1.5^{\circ} \mathrm{C}$ and $6^{\circ} \mathrm{C}$ (Pachauri et al. 2014). These conditions can pose a risk to vegetation due to increased evaporation, causing longer periods of drought and reduced availability of water in the soil for plants (Zahradníček et al. 2016), so several activities will suffer from climate change, especially agriculture (Thayer et al. 2020).

Agriculture is the most vulnerable area to the impacts of climate change (Clapp et al. 2018), significantly affecting food security for the growing population of the planet (Taylor 2018). According to Karimi et al. (2018), climate change will have impacts both on agricultural income and on the income and well-being of farming families. The climate is defined as the average of the atmospheric conditions that characterize a region and strongly influence ecosystems (Jylhä et al. 2010; de Souza Rolim and de 0. Aparecido 2016). To easily analyze, group, delimit and disseminate climatic characteristics of a region, the climatic classification systems emerged (Tapiador et al. 2019), among which there is a highlight for Flohn (1950), Camargo (1991), Holdridge (1967), Köppen and Geiger (1928) and Thornthwaite (1948) (Talchabhadel and Karki 2019) being the last three most used due to the facility to obtain and manipulate climatic data (Dubreuil et al. 2019). 
The Holdridge (1967) climate classification defines representative life zones for the different regions of the Earth, which reflect the conjuncture of these meteorological elements. The Holdridge classification system (1967), in turn, is based on the premise of biotemperature, defined by him as being a temperature range from $0^{\circ} \mathrm{C}$ to $30^{\circ} \mathrm{C}$, understands the temperature at which plant development occurs. The seasonal variation in temperature related to these extreme values implies the disorientation of essential metabolic activities, considerably affecting plant development (Tres et al. 2020).

The life zone system proposed by Holdridge (1967) associates biotemperature with the altitudinal belts and latitudinal regions of the study area. Thus, it becomes practical to understand the relationship between climate and plant typology, since the system relates altitude and latitude gradients in an attempt to explain the phytogeographic predominance of a given region (Tatli and Dalfes 2016; Tres et al. 2020).

In Argentina, (Derguy et al. 2019) used the Holdridge system to map the life zones, the authors observed the life zones with the greatest geographical extension Hot Temperate Dry Forest (15\% of the country) and Subtropical Dry Forest (9\%). Valerio et al. (2018) used the Holdridge system in Brazil to classify the climate of Rio Grande do Sul, delimiting eight life zones, of which the following stood out: humid basal rainforest (74.0\%); very humid forest / basal temperate humid forest (13.8\%); and humid forest / very humid basal temperate forest (8\%). Szelepcsényi et al. (2018) used the Holdridge system to assess ecological impacts generated by climate change in the Carpatos region, noting a possible expansion of altitudinal belts and the emergence of the subtropical dry forest class. Few studies have used the Holdridge classification (1967) on a national scale and in different climatic changes.

Thus, we seek to determine life zones for Brazil using the ecological classification of Holdridge (1967) in different scenarios of climate change.

\section{Material And Methods}

\subsection{Study region and data}

The study was developed throughout the Brazilian territory, with an extension of 8,547,403.5 $\mathrm{km}^{2}$. Among the main economic activities, there is an emphasis on the agribusiness sector responsible for $47 \%$ of exports and a share of around 37\% of GDP (Gross Domestic Product) (Guilhoto 2004), with great emphasis on grain production (soybeans and maize) and livestock in the Midwest region (Pinto et al. 2018) and fruit production producing approximately 40 million tons in 2017 (Neves et al. 2011; dos Santos et al. 2018). Also, there is a predominance of five biomes in the country, Amazon, Pantanal, Cerrado, Atlantic Forest, and Pampas, defining different vegetation characteristics (Overbeck et al. 2007).

\subsection{Climatic data}

We collected climatic data for 4942 locations (Fig. 1) to cover the entire Brazilian territory. The climatic elements collected were mean (Tm), maximum (Tmax) and minimum (Tmin) air temperatures $\left({ }^{\circ} \mathrm{C}\right)$ and rainfall $(\mathrm{P}, \mathrm{mm})$ on a daily scale from 1989-2019. Data were obtained by the National Aeronautics and 
Space Administration / Prediction of World Wide Energy Resources - NASA / POWER platform (Stackhouse et al. 2015). This data platform was developed to provide meteorological information derived in grids with a spatial resolution of $1^{\circ}$ (latitude-longitude).

\section{Calculation of potential evapotranspiration}

The calculation of potential evapotranspiration (PET) was performed using the Thornthwaite (1948) method modified by Camargo (1971), in which it simplified the method proposed by Thornthwaite, providing greater simplicity while maintaining its effectiveness (Eq. 1)

$P E T=F Q O T N D(1)$

where Qo ( $\mathrm{mm}$ day) is the daily extraterrestrial solar radiation expressed in evaporation equivalent, in the period considered, $\mathrm{T}\left({ }^{\circ} \mathrm{C}\right)$ is the mean air temperature during the period; $\mathrm{F}$ is the adjustment factor that varies with the mean annual temperature of the location ( for Tm up to $23^{\circ} \mathrm{C}, \mathrm{F}=0.01 ; \mathrm{Tm}=24^{\circ} \mathrm{C}, \mathrm{F}=$ $\left.0.0105 ; \mathrm{Tm}=25^{\circ} \mathrm{C}, \mathrm{F}=0.011 ; \mathrm{Tm}=26^{\circ} \mathrm{C}, \mathrm{F}=0.0115 ; \mathrm{Tm}>26^{\circ} \mathrm{C}, \mathrm{F}=0.012\right)$; and $\mathrm{ND}$ is the number of days in the period.

\section{Holdridge climate classification (1967)}

The SCC by Holdridge life zones establishes the determination of the local climate through the combination of altimetry, precipitation, optimum temperature values for the full physiological development of plants (Tbio), and the relationship between PET and precipitation.

The mean annual biotemperature (TbioA) was calculated to correspond to the temperature range in which the physiological processes of the plants do not become inactive $\left(0^{\circ} \mathrm{C}\right.$ to $\left.30^{\circ} \mathrm{C}\right)$. Temperatures below $0{ }^{\circ} \mathrm{C}$ and above $30^{\circ} \mathrm{C}$ cause a reduction in physiological processes and plant growth, thus, mean temperatures $<0^{\circ} \mathrm{C}$ have been corrected to $0^{\circ} \mathrm{C}$ and mean temperatures $>30^{\circ} \mathrm{C}$ have been corrected to equal $30^{\circ} \mathrm{C}$ (Equations 2-4) following the adaptation by Derguy et al. (2019) for the Holdridge system (1967).

Tbio $M=\{0$, if $\mathrm{Tm}<0 \mathrm{Tm}$, if $\mathrm{Tm} \geq 0$ (2)

TbioM $=\{30$,if $\mathrm{Tm}>30 \mathrm{Tm}$, if $\mathrm{Tm} \leq 30$ (3)

TbioA $=\frac{\sum_{x=1}^{12} T m}{12}$

where TbioM is the average monthly biotemperature $\left({ }^{\circ} \mathrm{C}\right) ; \operatorname{Tm}$ is the average monthly temperature $\left({ }^{\circ} \mathrm{C}\right)$; TbioA is the average annual biotemperature $\left({ }^{\circ} \mathrm{C}\right)$.

The annual precipitation $(P)$ was generated by the annual average of the region extracted from the climatological normal expressed in $\mathrm{mm}$. PET (PET / P) ratio was obtained by the ratio of annual evapotranspiration (PETanual) obtained by the method of (Thornthwaite and Mather 1955) by the annual precipitation $(P)$. 
The latitudinal limits (Fig. 2) were determined by calculating the mean annual basal biotemperature (TbioBA) which considers a change in Tbio of the region at sea level using a rate of $-0.6^{\circ} \mathrm{C} / \mathrm{Km}$. This rate (Eq. 5) was applied for each $\mathrm{Tm}$ in the region using altitude $(\mathrm{m})$ data extracted from a digital elevation model (MDE) of the Shuttle Radar Topography Mission (SRMT - http://srtm.csi.cgiar.org/ sitmdata) resulting in the mean monthly basal temperature (TmBM). Data obtained by the correction were adequate (Equations $6-7$ ) in the range of $0^{\circ} \mathrm{C}$ to $30^{\circ} \mathrm{C}$ to change them to the average monthly basal biotemperature (TbioBM), and with the average calculated on TbioBM, TbioBA was obtained (Eq. 8 ). Altitudinal belts were calculated using the altitude of the site (in meters) related to the latitudinal limits.

The frostline is used to delimit the boundaries between the warm temperate $\left(12^{\circ} \mathrm{C}\right)$ and subtropical $\left(24^{\circ} \mathrm{C}\right)$ latitudinal regions, according to the Holdridge SCC, this biotemperature range corresponds to $18^{\circ} \mathrm{C}$ and is calculated by the average between these regions.

$T m B M=($ Altitude $\times 0.006)+T m(5)$

TbioBM $=\{0$, if $\operatorname{TmBM}<0 \mathrm{Tm}$, if $\operatorname{TmBM} \geq 0$ (6)

$\operatorname{TbioBM}=\{30$, if $\mathrm{TmBM}>30 \mathrm{Tm}$, if $\mathrm{TmBM} \leq 30(7)$

TbioBA $=\frac{\sum_{x=1}^{12} \quad \text { TbioBM }}{12}$

Life zones (Fig. 3) were established by relating the calculated bioclimatic variables (Tbio, P, PET / P, and TbioBA) with the classification key established by Holdridge (1967), where each hexagon corresponds to a life zone. In this study, the transition zones determined by the equilateral triangle between the hexagons were assigned the closest life zone using the three determining variables for the classification of Holdridge (Tbio, P, and PET / P).

\section{Climate change scenario}

The possible scenarios of climate change were developed, changing one of the variables, air temperature $\left({ }^{\circ} \mathrm{C}\right)$ and rainfall $(\mathrm{mm})$ independently, and fixing the values of the other. The air temperature was increased by $1.5^{\circ} \mathrm{C}$ and $3.0^{\circ} \mathrm{C}$ as adopted by Pirttioja et al. (2015). For precipitation, the changes were 30 and $30 \%$, so that these temperature and precipitation values represent future projections simulated by the IPCC (Pachauri et al. 2014), making it possible to observe the various probable combinations, totaling 4 scenarios (Fig. 4).

\section{Spatialization of results}

The spatial interpolation of all climatic elements for all locations was by the method of Krigagem (Krige 1951), with spherical model, a neighbor and a spatial resolution of $0.25^{\circ}$. The cartographic projection system for calculating the area used was the equivalent conic of Albers. With the overlapping of the maps it was possible to obtain the climate maps for the TH classifications. All the steps for preparing the project are described in the Flowchart (Fig. 5). 


\section{Results And Discussions}

The climatic variables showed a high variation in the Brazilian territory (Fig. 6). The mean air temperature ranged from $13.1^{\circ} \mathrm{C}$ to $28^{\circ} \mathrm{C}$ with the highest values in the north of the country and the lowest in the south (Fig. 6A). The state of Pará, located in the northern region, obtained the highest values of air temperature, with an average of $27.5(0.49){ }^{\circ} \mathrm{C}$. The states of Santa Catarina and Rio Grande do Sul stood out as the coldest in the country, with an average of $18.0^{\circ} \mathrm{C}$. The locations of Belém - PA and Bom Jardim da Serra - SC were the warmest and coldest in the country, respectively, as also observed by Alvares et al. (2013).

Precipitation varied widely between regions of the country (Fig. 6C). The annual rainfall in Brazil was $1467( \pm 46.91) \mathrm{mm}$, with the states of Amapá and Amazonas having the highest volumes, with averages of $2999.78( \pm 152.15)$ and $2665.03( \pm 67.44) \mathrm{mm}$, respectively. On the other hand, the states of Rio Grande do Norte and Paraíba had the lowest average volumes of only $800.86( \pm 59.83)$ and $852.62( \pm$ 52.78) $\mathrm{mm}$ values similar to that found by Medeiros et al. (2019) and Santos et al. (2019). The potential evapotranspiration (PET), the average for Brazil was 980.09 ( \pm 22.32$) \mathrm{mm}$ (Fig. 6B), with the highest values being concentrated in the South and North regions of the country, and the states with the highest averages were the Rio Grande do Sul and Amazonas, with 1297.20 (16.74) and 1258.04 ( \pm 14.64$) \mathrm{mm}$, respectively. While the states of Rio Grande do Norte and Ceará showed the lowest PET values, with $670.90( \pm 31.17)$ and $680.31( \pm 39.19) \mathrm{mm}$.

The altitude spatialization demonstrated its variability across the Brazilian territory (Fig. 6D). The altitude in Brazil varied from 0 to $1601 \mathrm{~m}$, with the extremes of the country having altitudes below $200 \mathrm{~m}$. On the other hand, the southeast regions showed an average of $645.8 \mathrm{~m}$, locating the highest municipalities in the country, Campos do Jordão - SP, Itamonte - MG, and Marmelópolis - MG, with altitudes of 1601, 1592, and $1570 \mathrm{~m}$. Locations with high altitudes generally have a temperature below the regional average, considering that with the increase in altitude, the volume in the atmosphere is reduced, making it difficult to stir air molecules, thus having an inversely proportional relationship between temperature and altitude as observed by Lancaster (1980).

Brazil has shown a great variation for biotemperature, with an average of $22.9( \pm 1.83){ }^{\circ} \mathrm{C}$ (Fig. 7). Biotemperature decreases in the north-south direction of Brazil, and the northern region was almost entirely classified in the biotemperature class greater than $24^{\circ} \mathrm{C}$ and less than or equal to $26^{\circ} \mathrm{C}$. A small part of northeastern Pará, southeastern Amapá, and northern Maranhão were the regions classified in the highest biotemperature class (greater than $26^{\circ} \mathrm{C}$ ). The states with the highest values of biotemperature were Pará, Maranhão, and Amapá, with $27.48( \pm 0.94){ }^{\circ} \mathrm{C}, 27.28( \pm 0.82){ }^{\circ} \mathrm{C}$ and $27.09( \pm 1.16)^{\circ} \mathrm{C}$, respectively. On the other hand, the states of Rio Grande do Sul, Santa Catarina, and Paraná, the states of the southern region of the country, had the lowest biotemperatures, $17.96( \pm 2.80)^{\circ} \mathrm{C}, 18.02( \pm 3.30)^{\circ} \mathrm{C}$ and $19.08( \pm 2.80)^{\circ} \mathrm{C}$, respectively. In these colder regions, some crops have great representativeness, such as English potatoes, grapes, and apples (IBGE 2018). 
Basal biotemperature ranged from $16^{\circ} \mathrm{C}$ to $28.6^{\circ} \mathrm{C}$, with an average of $24.9^{\circ} \mathrm{C}$, with higher values concentrated in the northern region of the country, while the lowest values were in the southern region (Fig. 7B). The states with the highest and lowest biotemperatures were Pará and Rio Grande do Sul, with an average of $28.1(0.2)^{\circ} \mathrm{C}$ and $20.0(1)^{\circ} \mathrm{C}$, respectively. The ratio between PET and $\mathrm{P}$, after spatialization, showed that the most humid regions of the country are located in the north, on the other hand, the northeast stands out with the driest region (Fig. 7C).

Brazil demonstrated 3 altitudinal belts, basal, premontane, and low montane (Fig. 8A). In the country, $66.24 \%$ were found to belong to the basal elevation belts, concentrating a large part of the North, Northeast, and Midwest regions. The premontano belts corresponded to $29.95 \%$ of the national territory, going from the central region to the south of the country. The mountainous low belts only $3.79 \%$ of the territory of Brazil, located mainly in the South and regions of high altitudes in the Southeast. These regions are problematic for the cultivation of some crops such as soy, maize, and sugarcane, however, it is the regions with the greatest aptitude for the cultivation of seasoned fruits such as apple, pear, plum, and grapevine (Pio et al. 2018).

Three latitudinal regions were found in Brazil, Tropical, Subtropical, and Hot temperate (Fig. 8B). The most representative latitudinal region was the tropical region, with $90.13 \%$ of the total area, which is found in the North, Midwest, Southeast, and Northeast regions. With $9.51 \%$, the subtropical latitudinal region was the second most found in Brazil, present mainly in the coastal states of the Southeast region and the south region, results according to Derguy et al. (2019) on the border between the state of Paraná and Argentina. The warm temperate latitudinal region represented $0.35 \%$ of Brazil's surface, being restricted to the extreme south of the State of Rio Grande do Sul.

With the increase in temperature, there was a reduction in the subtropical and temperate latitudinal region in the south and southeast of the country and expansion of the tropical region in other locations. For the altitudinal belts, there was an expansion of the basal belt due to the increase in the average biotemperature of the region. The precipitation variation scenarios remained identical to the current scenario for the altitudinal belts (Fig. 8A) and latitudinal regions (Fig. 8B).

Regarding the humidity provinces, Brazil presented only four types, super-humid, humid and sub-humid, and semi-arid (Fig. 8C). Most of the country was classified as wet, encompassing $58.16 \%$ of the Brazilian territory, concentrating the South, Midwest, Southeast, and part of the other regions, providing good agricultural development in much of the country (Tweed et al. 2018). The super humid province was registered in $32.93 \%$ of the Brazilian territory with the highest concentration in the northern region and one occurrence in the southern region. The provinces and sub-humid and semi-arid were less significant, representing around $8.66 \%$ and $0.22 \%$, respectively concentrated in the northern region of Minas Gerais and the northeast region of the country. The northern region was the region that most demonstrated the super humid province, mainly in the states of Amapá, Rondônia, and Roraima, which were classified as super humid, due to those with higher levels of precipitation. Part of the northeast region, mainly the interior, concentrated the only areas of the sub-humid and semi-arid province, with emphasis on the state 
of Bahia, which has $62.22 \%$ of its territory belonging to the sub-humid province and $2.79 \%$ to the semiarid province. Bahia is a major producer of soybean, maize, and cotton (IBGE 2018).

In the $1.5^{\circ} \mathrm{C}$ and $3^{\circ} \mathrm{C}$ temperature rise scenarios there was a predominance of super humid provinces in the north of Amazonas and Amapá, semi-arid and sub-humid provinces in the northeast region. With the $30 \%$ reduction in rainfall, there is a predominance of arid, semi-arid, and sub-humid provinces in the northeast region and humid provinces in the rest of the country. The $30 \%$ increase in rainfall is predominant in the super humid provinces in the northern and southern regions, and the humid and subhumid provinces in the northeastern region.

Brazil presented for the current scenario (S1) a total of 15 approximate life zones (Fig. 9A) and 30 life zones including transition regions (Fig. 9B) in the current scenario, 5 less compared to the work of Tres et al. (2020), in which he presented 35 life zones. Of the 15 approximate life zones (Fig. 9A) there is a predominance of the $60.57 \%$ basal tropical rainforest zones (Table 1) with the highest concentration in the north of the Midwest region, most of the North and Northeast regions including the coast. $\mathrm{E}$ Premontane tropical rainforest in $17.30 \%$ (Table 1) of the Brazilian territory with predominance in the south of the Midwest region, and most of the Southeast region, and the State of Acre. Considering the transition zones (Fig. 9B), there is a predominance of the life zones in the basal tropical rainforest in $29.67 \%$ of the Brazilian territory with the highest occurrence in the north of Mato Grosso, Rondônia, and the extreme north of the northern region in the state of Amapá, and the zone due Rainforest basal humid corresponding to $15.45 \%$ located in the center of the State of Mato Grosso and east of the North region.

The Midwest, Northeast, and Northeast regions of the Southeast showed tropical climates, classified as Basal tropical rainforest and Premontane tropical rainforest (Fig. 9A) corresponding to the main life zones in the country, concentrating $60.57 \%$ and $17,30 \%$ (Table 1 ) of the Brazilian territory respectively. These regions are major producers of Soy, Corn, and Coffee (IBGE 2018). The South region presented subtropical climates where the most present areas of life were the humid premontane subtropical forest and the low humid subtropical montane forest, which represent $51.71 \%$ and $26.50 \%$ of the region, respectively.

The capital of Brazil, Brasília, presented the zone of life, humid premontane rainforest. Other capitals such as São Paulo and Rio de Janeiro were classified as humid premontane subtropical forests. The warmest and coldest locations in the country, Belém - PA and Bom Jardim - SC da Serra, were classified as Basal humid tropical forest and Low humid subtropical montane forest, respectively. The two municipalities are located at the extremes of the country, to the north and south, in addition to having a large difference in altitude, demonstrating the impact of latitude and altitude on air temperature (Reynolds et al. 2018; Sunday et al. 2019).

The sensitivity analysis demonstrated the impact of rainfall and air temperature on the Holdridge (1967) classification system and can be seen in Fig. 10 (S2 S3 S4 S5). The increase of $1.5^{\circ} \mathrm{C}$ and $3.0^{\circ} \mathrm{C}$ in the average air temperature caused a variation between the number of life zones to 18 and 11, respectively. It also reduced the area of the humid basal subtropical forest living area to $48.92 \%$ and $48.95 \%$ (Table 1 ) 
and an increase in the area of the dry basal tropical forest area, surpassing that which was the largest in the current scenario, representing only $21.96 \%$ and $34.58 \%$, (Table 1 ) respectively.

To scenario S4 (30\% reduction in average precipitation), there were 16 life zones, with an emphasis on the life zones Dry basal tropical forest, with $49.87 \%$ (Table 1) of all Brazilian territory in the regions to the north of the Midwest, most of the North region encompassing the entire state of Rondônia and the western and coastal regions of the Northeast. The wetland premontane tropical forest with $13.13 \%$ (Table 1) had the highest occurrence in the west of the North region, South of the Midwest region, and west of Minas Gerais. S4 has a higher percentage in dry life zones compared to S1, totaling $65.57 \%$ of the surface, whereas in $\mathrm{S} 1$ these life zones have low representation.

The scenario with an increase of $30 \%$ in average precipitation (S5) showed great variation to the scenario S1 with 19 life zones, 4 is more than the current scenario (S1) (Fig. 10A). The most prevalent area of life in this scenario was a humid basal tropical forest with $50.12 \%$ of all Brazilian territory (Table 1 ), concentrated in a large part of the northern region and the northern part of the Midwest. The wetland Premontano tropical rainforest was the second largest in territorial extension with $10.09 \%$, mainly to the west of the North region, southeast of the Midwest region, south of Minas Gerais, and little occurrence in the central region of Paraná and Litoral de São Paulo, Rio de Janeiro and Paraná.

In all the scenarios evaluated, the tropical life zones were concentrated in the Amazon biome in the north of the country, Cerrado, Caatinga, Pantanal, and Atlantic forest in the Midwest, North, Southeast, and Northeast regions, whereas the subtropical life zones are located in a great part of the Atlantic Forest biomes in a strip that extends from the south of the country to the coast of the Southeast region, the hot temperate life zones occurred in the pampa biome in the extreme south of the country with a small strip in the south of the State of Rio Grande do Sul (Fig. 11). 
Table 1

The proportion of occurrences of Holdridge life zones (1967) for each scenario of climate change in the Midwest.

\begin{tabular}{|c|c|c|c|c|c|}
\hline LIFE ZONES & (CURRENT) & S2 & S3 & S4 & S5 \\
\hline Subtropical basal dry forest & - & 0.00151 & 0.000713 & - & - \\
\hline Subtropical basal moist forest & - & - & 0.000247 & - & - \\
\hline $\begin{array}{l}\text { Subtropical lower montane dry } \\
\text { forest }\end{array}$ & - & - & - & 0.008221 & - \\
\hline $\begin{array}{l}\text { Subtropical lower montane moist } \\
\text { forest }\end{array}$ & 3.000557 & 0.207612 & 0.108458 & 3.117392 & 0.259522 \\
\hline $\begin{array}{l}\text { Subtropical lower montane wet } \\
\text { forest }\end{array}$ & 0.124963 & 0.389767 & - & - & 2.865908 \\
\hline Subtropical premontane dry forest & 0.047651 & 0.00203 & - & 2.148529 & 0.025002 \\
\hline $\begin{array}{l}\text { Subtropical premontane moist } \\
\text { forest }\end{array}$ & 5.754455 & 3.782774 & 3.134764 & 4.23937 & 2.667315 \\
\hline Subtropical premontane wet forest & 0.58654 & 0.71189 & 0.705652 & - & 3.69572 \\
\hline Tropical basal dry forest & 1.376475 & 21.96326 & 34.58323 & 49.87651 & 9.570618 \\
\hline Tropical basal moist forest & 60.57437 & 48.92394 & 48.9537 & 11.09982 & 50.12662 \\
\hline Tropical basal thorn woodland & - & 0.515753 & - & 0.057943 & - \\
\hline Tropical basal very dry forest & 4.374661 & 8.337951 & 4.806903 & 5.290974 & 3.045076 \\
\hline Tropical basal wet forest & - & - & - & - & 3.58313 \\
\hline Tropical lower montane dry forest & - & - & - & 0.002012 & - \\
\hline $\begin{array}{l}\text { Tropical lower montane moist } \\
\text { forest }\end{array}$ & 0.267617 & 0.147788 & 0.015253 & 0.265419 & 0.053773 \\
\hline Tropical lower montane wet forest & - & 0.041119 & - & - & 0.213774 \\
\hline Tropical premontane desert scrub & - & - & - & 0.03421 & - \\
\hline Tropical premontane dry forest & 4.680224 & 1.922695 & 0.443228 & 8.213867 & 4.059556 \\
\hline Tropical premontane moist forest & 17.30891 & 12.92914 & 6.985021 & 13.13398 & 8.557078 \\
\hline Tropical premontane rain forest & - & - & - & - & 0.631127 \\
\hline $\begin{array}{l}\text { Tropical premontane thorn } \\
\text { woodland }\end{array}$ & 0.323096 & 0.006781 & - & 2.158418 & 0.200982 \\
\hline Tropical premontane wet forest & 1.227129 & 0.098611 & 0.262841 & - & 10.09184 \\
\hline $\begin{array}{l}\text { Warm temperate lower montane } \\
\text { moist forest }\end{array}$ & 0.352374 & 0.016975 & - & 0.35236 & 0.218477 \\
\hline
\end{tabular}




\begin{tabular}{|llllll|}
\hline LIFE ZONES & (CURRENT) & S2 & S3 & S4 & S5 \\
\hline $\begin{array}{l}\text { Warm temperate lower montane } \\
\text { wet forest }\end{array}$ & - & - & - & - & 0.133514 \\
\hline $\begin{array}{l}\text { Warm temperate premontane } \\
\text { moist forest }\end{array}$ & 0.000975 & 0.0004 & - & 0.000975 & - \\
$\begin{array}{l}\text { Warm temperate premontane wet } \\
\text { forest }\end{array}$ & - & - & - & - & 0.000975 \\
\hline
\end{tabular}

\section{Conclusion}

Brazil has 15 life zones, and in the current scenario, Basal Tropical Rainforest in and Prémontano Tropical Rainforest are the most expressive, representing $60.5 \%$ and $17.3 \%$ of the Brazilian territory.

As the air temperature rises, there is a decline in the wet life zones, however, it remains predominant about the others, so the Basal Wet Tropical Forest becomes the most present in the country and the Dry Basal Tropical Forest the second most expressive, representing for the increase of $1.5^{\circ} \mathrm{C}$ (S2) $48.9 \%$ and $21.9 \%$ and for the increase of $3.0^{\circ} \mathrm{C}(\mathrm{S} 3) 48.9 \%$ and $34.5 \%$.

The 30\% reduction in rainfall (S4) is the most prevalent area of the Dry Basal Tropical Forest. On the other hand, the increase of $30 \%$ (S5) changes the country's climate classification, increasing to 19 life zones, with only the Basal Humid Tropical Forest representing $50.1 \%$ of the country.

\section{Declarations}

Conflict of Interest: The authors have no conflict of interest

Funding Statement: This study was financed in part by the Coordenação de

Aperfeiçoamento de Pessoal de Nível Superior - Brasil (CAPES) - Finance Code 001.

Availability of data and material: The data/ material is opened

Code availability: The software used was python and scripts are available

Ethics approval: 'Not applicable'

Consent to participate: 'Not applicable'

Consent for publication: 'Not applicable'

\section{Author contributions}

Rafael Fausto de Lima: Formal analysis, Investigation, Data curation, Writing - 
Original Draft, Writing - Review \& Editing, Visualization.

Lucas Eduardo de Oliveira Aparecido: Conceptualization, Methodology, Supervision, Project administration.

João Antonio Lorençone: Writing - Review \& Editing.

Pedro Antonio Lorençone: Writing - Review \& Editing.

José Reinaldo da Silva Cabral de Moraes: Writing - Review \& Editing.

Kamila Cunha de Meneses: Writing - Review \& Editing.

Conflict of Interest: The authors declare that they have no conflict of interest.

\section{References}

1. Alvares CA, Stape JL, Sentelhas PC, de Moraes Gonçalves JL (2013) Modeling monthly mean air temperature for Brazil. Theor Appl Climatol 113:407-427. https://doi.org/10.1007/s00704-012-07966

2. Camargo A (1971) São Paulo State Water Balance. Bol Inst Agronômico Camp 116:1-24

3. Camargo AP (1991) Climatic classification for zoning of agroclimatic aptitude. Brazilian Journal of Agrometeorology 8:126-131

4. Clapp J, Newell P, Brent ZW (2018) The global political economy of climate change, agriculture and food systems. J Peasant Stud 45:80-88

5. de Souza Rolim G, de O. Aparecido LE (2016) Camargo, Köppen and Thornthwaite climate classification systems in defining climatical regions of the state of São Paulo, Brazil. Int J Climatol 36:636-643

6. Derguy MR, Frangi JL, Drozd AA et al (2019) Holdridge Life Zone Map: Republic of Argentina. Gen Tech Rep 51

7. dos Santos KFT, dos Santos MLGT, Cella D, Spada RK (2018) Fruticulture: study of papaya international trade. Rev Technological Interface 15:323-335

8. Dubreuil V, Fante K, Planchon O, Sant'Anna Neto J (2019) Climate change evidence in Brazil from Köppen's climate annual types frequency. Int J Climatol 39:1446-1456

9. Flohn H (1950) Neue Anschauungen über die allgemeine Zirkulation der Atmosphäre und ihre klimatische Bedeutung. Erdkunde 4:141-162

10. Guilhoto J (2004) Regional Importance of the Agribusiness in the Brazilian Economy. SSRN Electron J. https://doi.org/10.2139/ssrn.2425747

11. Herman JD, Quinn JD, Steinschneider S et al (2020) Climate adaptation as a control problem: Review and perspectives on dynamic water resources planning under uncertainty. Water Resour Res 
56:e24389

12. Holdridge LR (1967) Life zone ecology. Tropical Science Center, San Jose

13. IBGE (2018) IBGE Automatic Recovery System - SIDRA: Municipal Agricultural Production. https://sidra.ibge.gov.br/home/pnadcm. Accessed 28 May 2020

14. Jylhä K, Tuomenvirta H, Ruosteenoja K et al (2010) Observed and projected future shifts of climatic zones in Europe and their use to visualize climate change information. Weather Clim Soc 2:148-167

15. Karimi V, Karami E, Keshavarz M (2018) Climate change and agriculture: Impacts and adaptive responses in Iran. J Integr Agric 17:1-15

16. Köppen W, Geiger R (1928) Klimate der Erde. Verlag Justus Perthes. (Wall-Map, Gotha

17. Krige DG (1951) A statistical approach to some basic mine valuation problems on the Witwatersrand. J South Afr Inst Min Metall 52:119-139

18. Lancaster I (1980) Relationships between altitude and temperature in Malawi. South Afr Geogr J 62:89-97

19. Medeiros ES de, Lima RR de, Olinda RA de, Santos CAC dos (2019) Modeling Spatiotemporal Rainfall Variability in Paraíba, Brazil. Water 11:1843. https://doi.org/10.3390/w11091843

20. Neves MF, Trombin VG, Lopes FF et al (2011) The citrus sector in Brazil. In: The orange juice business. Wageningen Academic Publishers, Wageningen, pp 18-20

21. Overbeck G, Muller S, Fidelis A et al (2007) Brazil's neglected biome: The South Brazilian Campos. Perspect Plant Ecol Evol Syst 9:101-116. https://doi.org/10.1016/j.ppees.2007.07.005

22. Pachauri RK, Allen MR, Barros VR et al (2014) Climate Change 2014: Synthesis Report. Contribution of Working Groups I, II and III to the Fifth Assessment Report of the Intergovernmental Panel on Climate Change. IPCC, Geneva

23. Pinto HE, Teixeira SM, Ferreira MDP (2018) Economic implications of taxing exports on agribusiness in Central-West Brazil. Field Interactions Gd 529-542. https://doi.org/10.20435/inter.v19i3.1661

24. Pio R, Souza FBM de, Kalcsits $L$ et al (2018) Advances in the production of temperate fruits in the tropics. Acta Sci Agron 41:39549. https://doi.org/10.4025/actasciagron.v41i1.39549

25. Pirttioja N, Carter T, Fronzek S et al (2015) Temperature and precipitation effects on wheat yield across a European transect: a crop model ensemble analysis using impact response surfaces. Clim Res 65:87-105. https://doi.org/10.3354/cr01322

26. Reynolds PL, Stachowicz JJ, Hovel K et al (2018) Latitude, temperature, and habitat complexity predict predation pressure in eelgrass beds across the Northern Hemisphere. Ecology 99:29-35

27. Santos C, Brasil Neto R, da Silva R, Costa S (2019) Cluster Analysis Applied to Spatiotemporal Variability of Monthly Precipitation over Paraíba State Using Tropical Rainfall Measuring Mission (TRMM) Data. Remote Sens 11:637. https://doi.org/10.3390/rs11060637

28. Stackhouse PW, Westberg D, Hoell JM et al (2015) Prediction of Worldwide Energy Resource (POWER)-Agroclimatology methodology-(1.0 latitude by 1.0 longitude spatial resolution). Hampton NASA Langely Res Cent 
29. Sunday J, Bennett JM, Calosi P et al (2019) Thermal tolerance patterns across latitude and elevation. Philos Trans R Soc B 374:20190036

30. Szelepcsényi Z, Breuer H, Kis A et al (2018) Assessment of projected climate change in the Carpathian Region using the Holdridge life zone system. Theor Appl Climatol 131:593-610

31. Talchabhadel R, Karki R (2019) Assessing climate boundary shifting under climate change scenarios across Nepal. Environ Monit Assess 191:520

32. Tapiador FJ, Moreno R, Navarro A et al (2019) Climate classifications from regional and global climate models: Performances for present climate estimates and expected changes in the future at high spatial resolution. Atmospheric Res 228:107-121

33. Tatli H, Dalfes HN (2016) Defining Holdridge's life zones over Turkey. Int J Climatol 36:3864-3872

34. Taylor M (2018) Climate-smart agriculture: what is it good for? J Peasant Stud 45:89-107. https://doi.org/10.1080/03066150.2017.1312355

35. Thayer AW, Vargas A, Castellanos AA et al (2020) Integrating Agriculture and Ecosystems to Find Suitable Adaptations to Climate Change. Climate 8:10

36. Thornthwaite C, Mather J (1955) The water balance publications in Climatology, 8 (1). DIT Lab Climatol Centerton NJ USA

37. Thornthwaite CW (1948) An approach toward a rational classification of climate. Geogr Rev 38:5594

38. Tres A, França Tetto A, Viana Soares R et al (2020) Ecological life zones of Brazil. Forest 50:1575. https://doi.org/10.5380/rf.v50i3.64833

39. Tweed $\mathrm{S}$, Celle-Jeanton $\mathrm{H}$, Cabot $\mathrm{L}$ et al (2018) Impact of irrigated agriculture on groundwater resources in a temperate humid region. Sci Total Environ 613:1302-1316

40. Valerio DA, Tres A, Tetto AF et al (2018) Holdridge life zone classification for the southern brazilian state 'Rio Grande do Sul. ' Cienc Florest 28:1776-1788

41. Zahradníček P, Farda A, Skalák P et al (2016) Projection of drought-inducing climate conditions in the Czech Republic according to Euro-CORDEX models. Clim Res 70:179-193

\section{Figures}




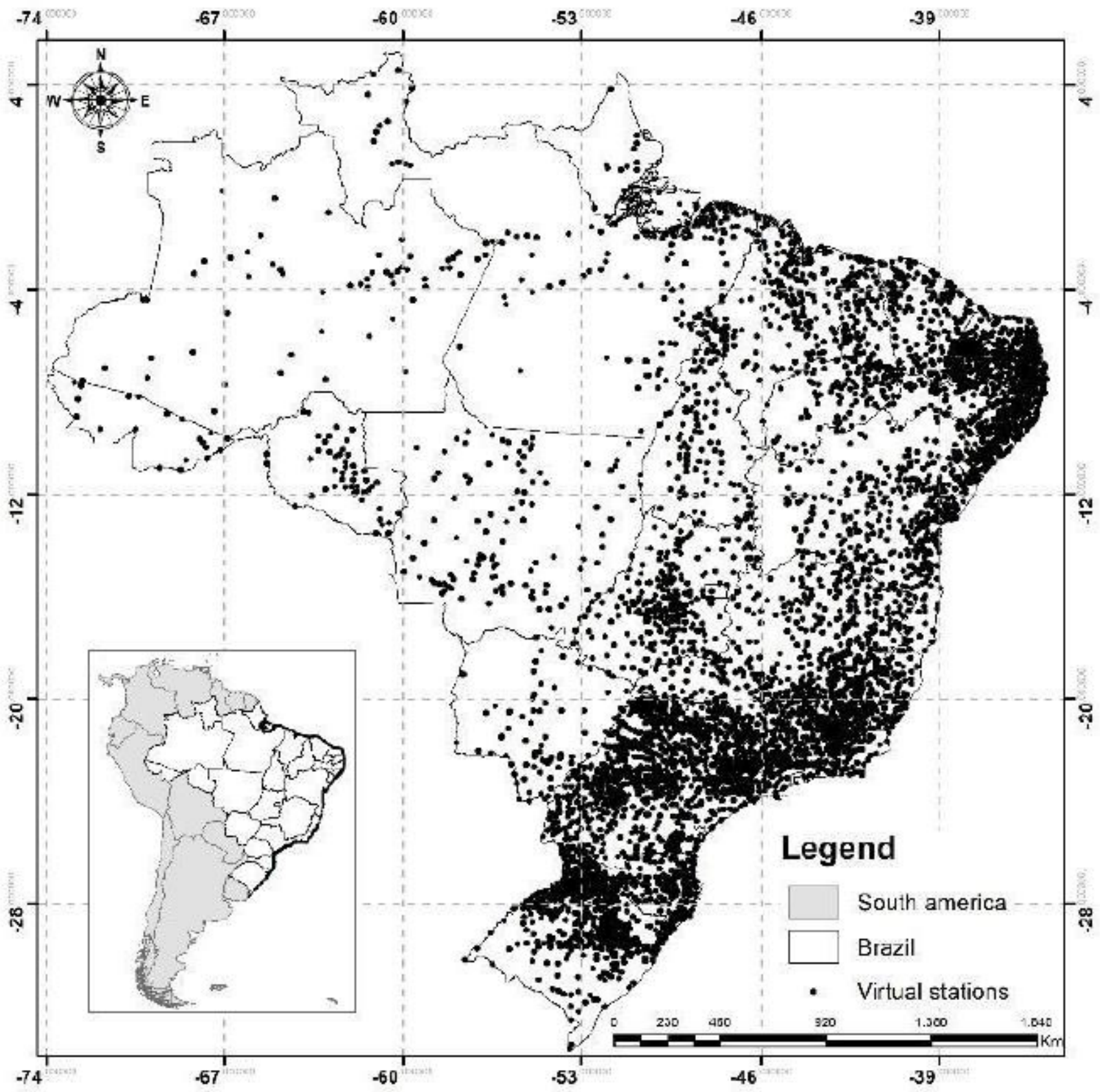

Figure 1

Location map of the study area. 


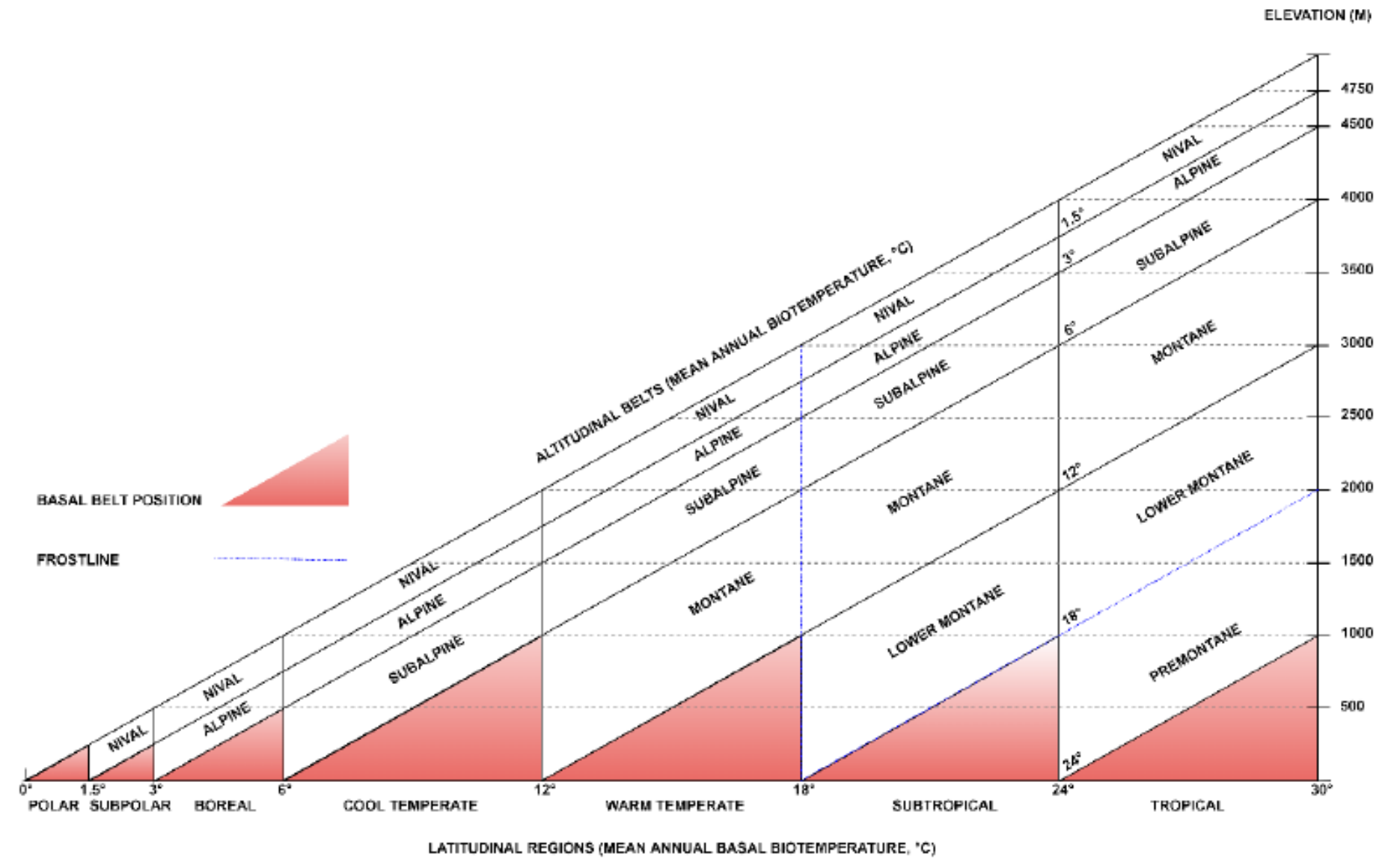

Figure 2

Diagram for determining altitudinal and latitudinal belts by Holdridge (1967). 


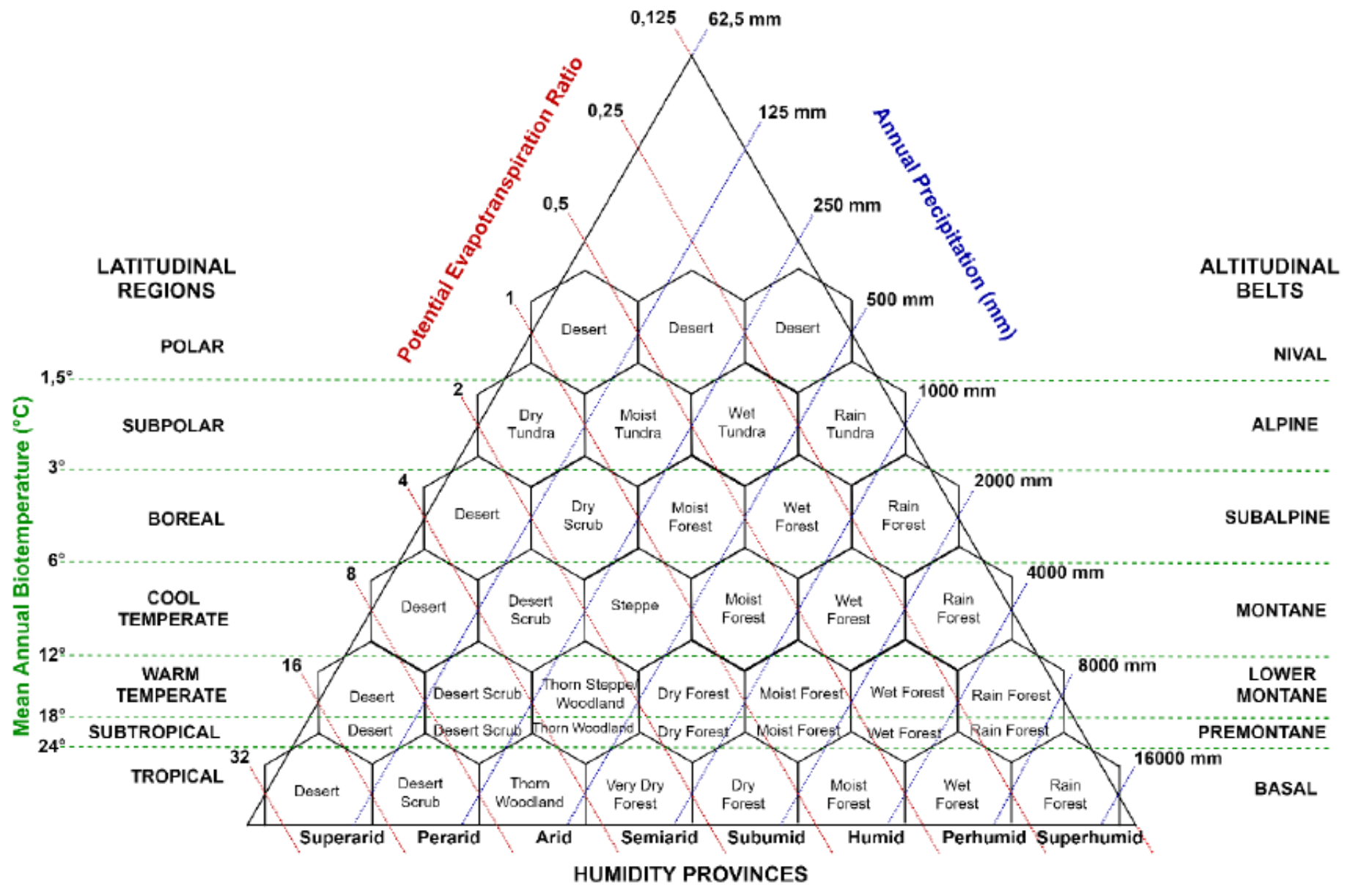

Figure 3

Holdridge climate classification system (1967). Adapted from Derguy et al. (2019). 


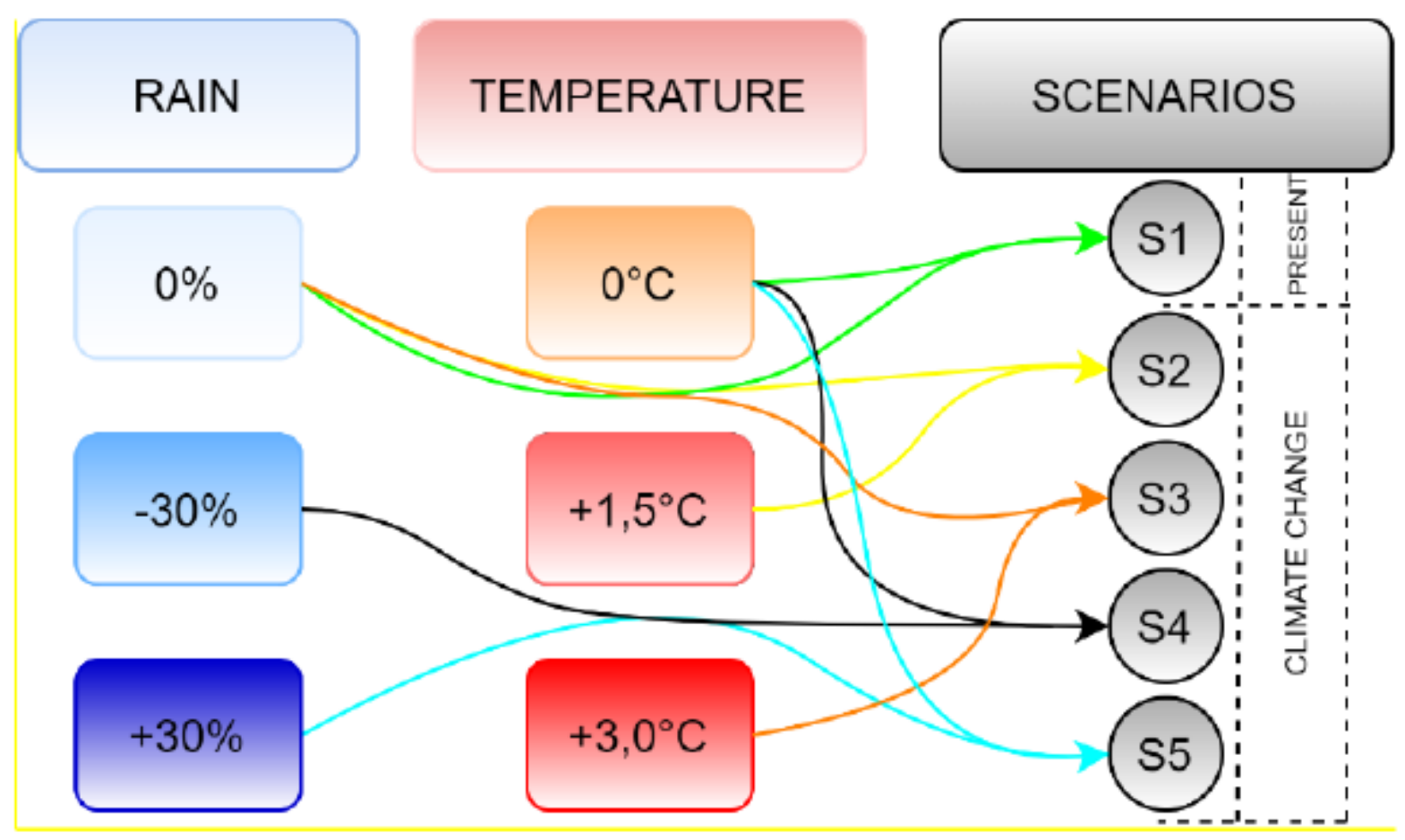

Figure 4

Simulated climate change scenario for Brazil. 


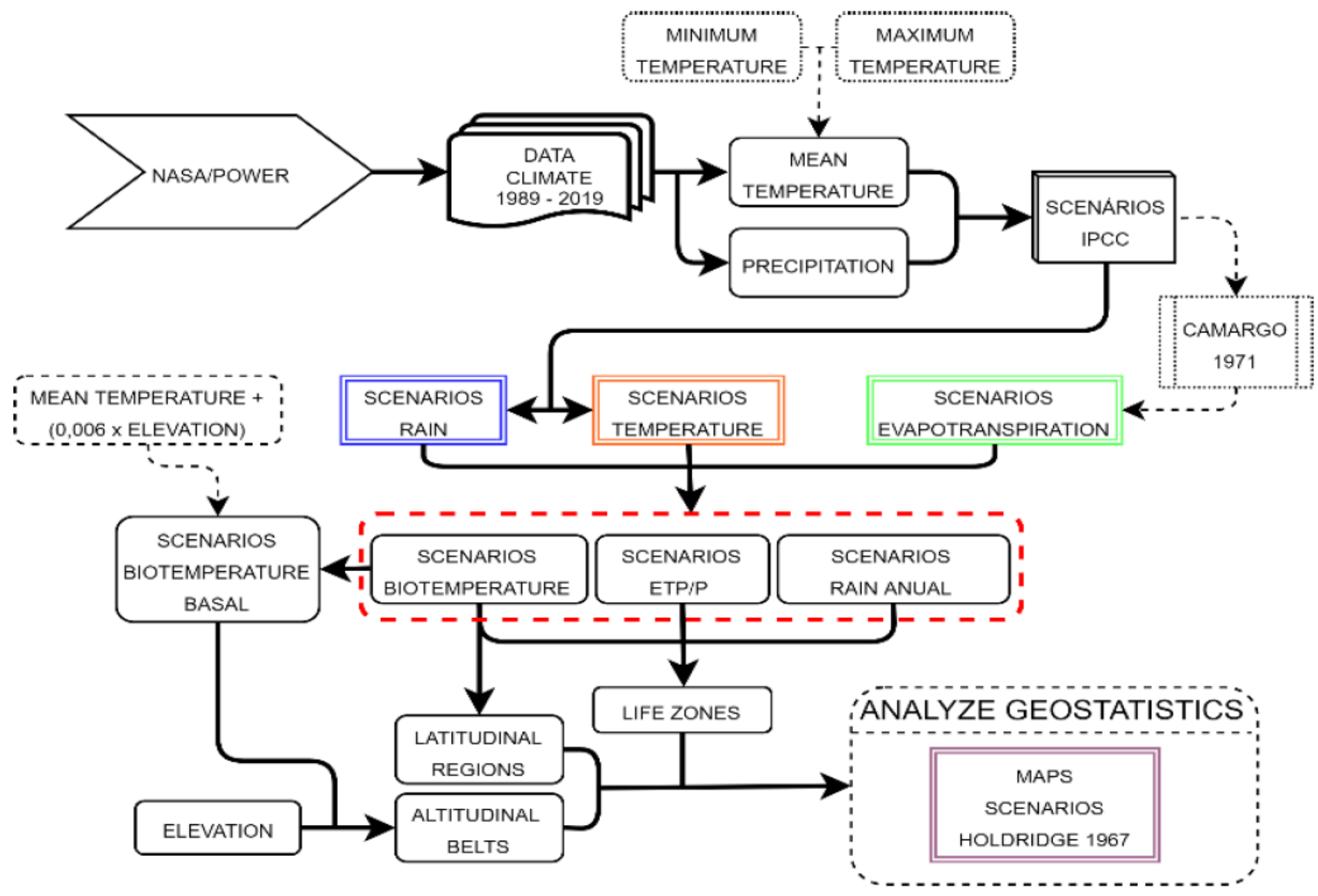

Figure 5

Flowchart of steps performed in the project. 

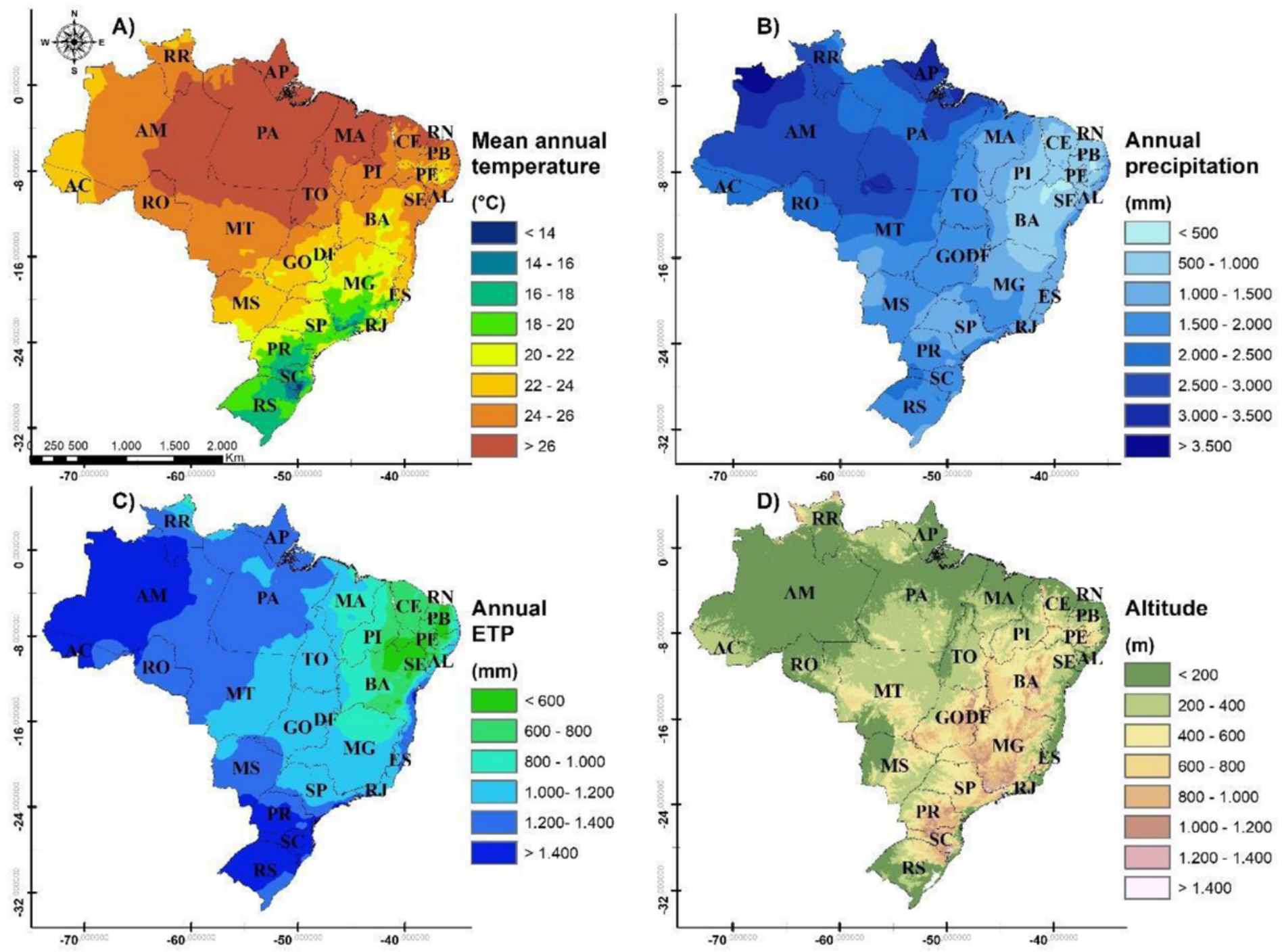

Figure 6

Climatic variables and altitude of the Brazilian territory. 

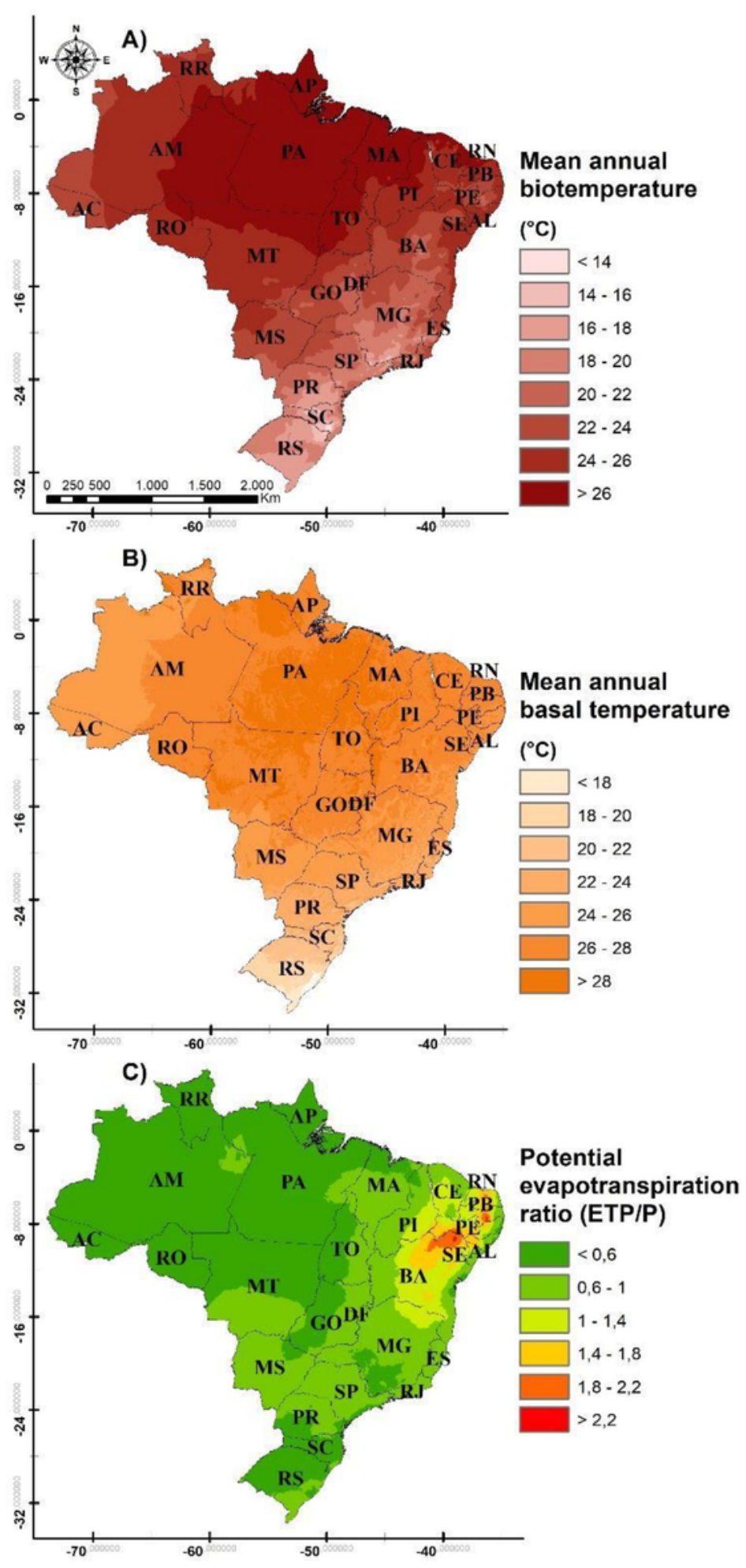

Figure 7

Holdridge (1967) bioclimatic variables for the current scenario. 

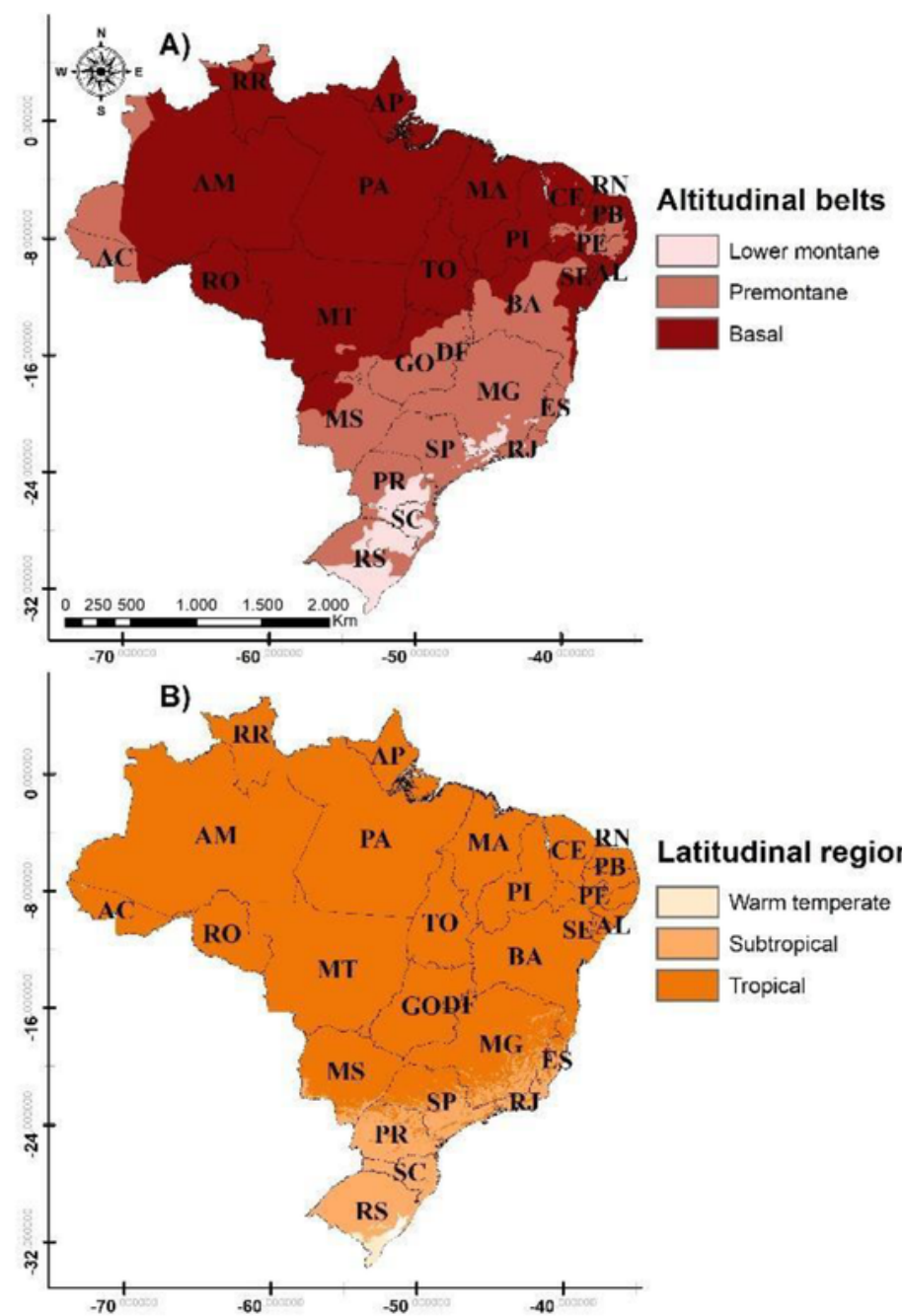

Latitudinal regions

$\square$ Warm temperate
$\square$ Subtropical
$\square$ Tropical

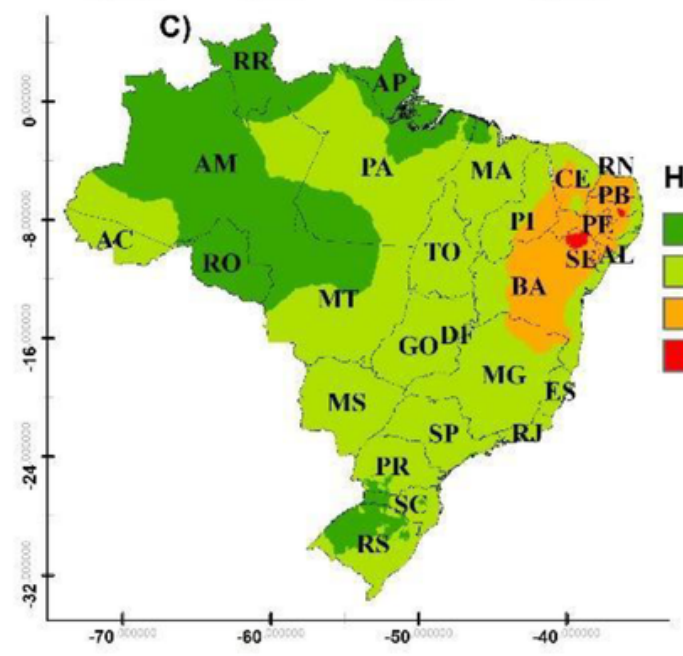

Figure 8

Altitudinal belts, latitudinal regions, and humidity provinces for the current scenario. 

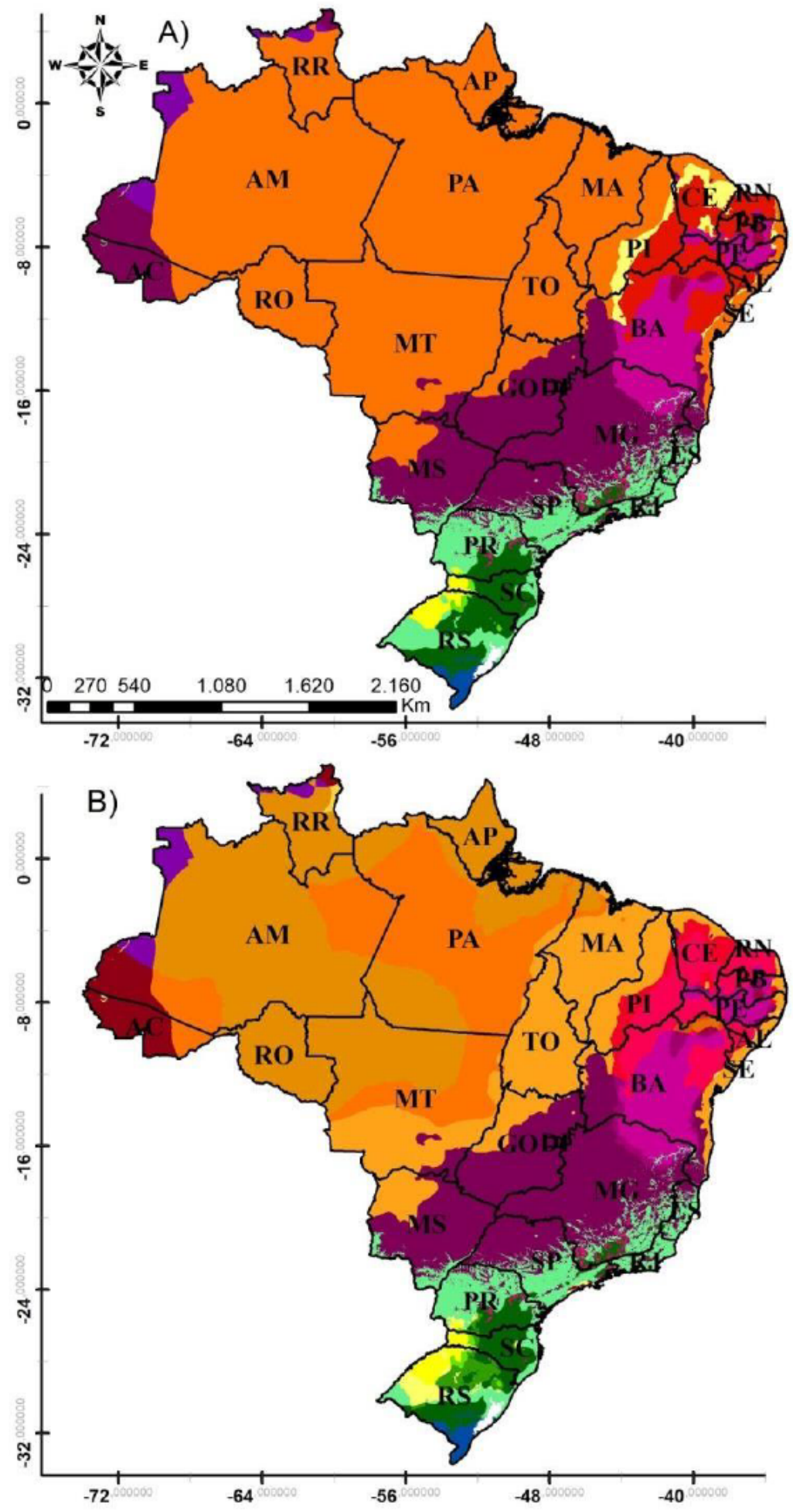

HOLDRIDGE (1947) LIFE ZONES SCENARIO ATUAL

Tropical premontane wet forest

Tropical premontane thorn woodland/dry forest

Tropical premontane thorn woodland

Tropical premontane moist/wet forest

Tropical premontane moist forest

Tropical premontane dry moist/forest

Tropical premontane dry forest

Tropical lower montane moist/wet forest

Tropical lower montane moist forest

Tropical basal very dry/dry forest

Tropical basal very dry forest/dry forest/moist forest

Tropical basal very dry forest

Tropical basal thorn woodland/very dry forest/dry

Tropical basal thorn woodland/dry forest

Tropical basal moist/wet forest

Tropical basal moist forest

Tropical basal dry moist/forest

Tropical basal dry forest/moist forest/wet forest

Tropical basal dry forest

Subtropical premontane wet forest

Subtropical premontane moist/wet forest

Subtropical premontane moist forest

Subtropical premontane dry moist/forest

Subtropical premontane dry forest

Subtropical lower montane wet forest

Subtropical lower montane moist/wet forest

Subtropical lower montane moist forest

Warm Temperate lower montane moist forest

Warm Temperate lower montane moist/wet forest

Warm Temperate premontane moist forest

\section{Figure 9}

Holdridge (1967) climate classification map for the current scenario. 

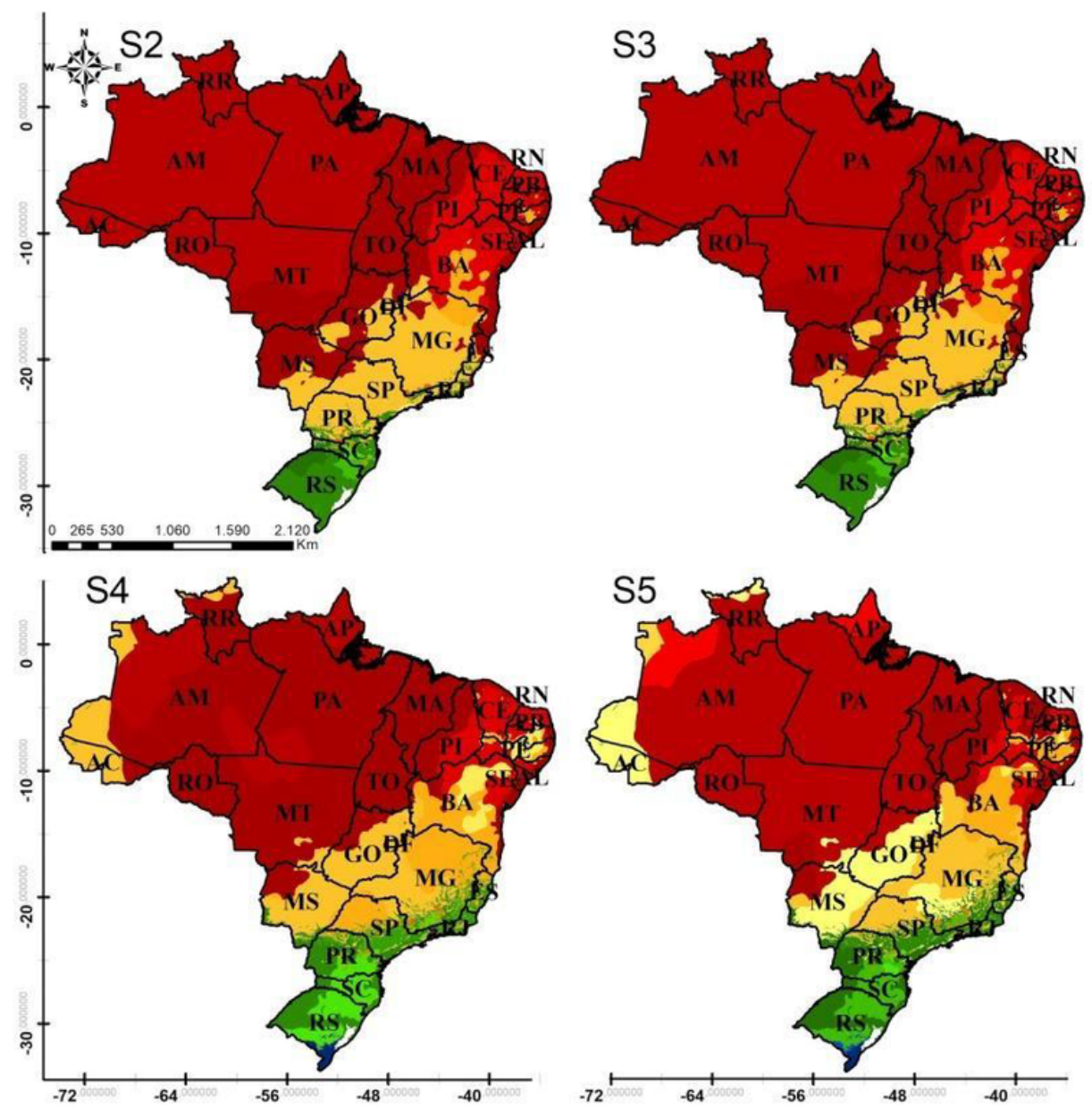

HOLDRIDGE (1947) LIFE ZONES

CLIMATE CHANGE SCENARIOS

$\square$ Tropical basal dry forest

Tropical basal moist forest

Tropical basal thorn woodland

Tropical basal very dry forest

Tropical basal wet forest

Tropical lower montane dry forest

Tropical lower montane moist forest

Tropical lower montane wet forest

Tropical premontane desert scrub

Tropical premontane dry forest

Tropical premontane moist forest

Tropical premontane rain forest

Tropical premontane thorn woodland

Tropical premontane wet forest

Subtropical basal dry forest

Subtropical basal moist forest

Subtropical lower montane dry forest

Subtropical lower montane moist forest

Subtropical lower montane wet forest

Subtropical premontane dry forest

Subtropical premontane moist forest

Subtropical premontane wet forest

Warm temperate lower montane moist forest

Warm temperate lower montane wet forest

Warm temperate premontane moist forest

Warm temperate premontane wet forest

\section{Figure 10}

Climate change scenarios for the Holdridge (1967) life zone system. 


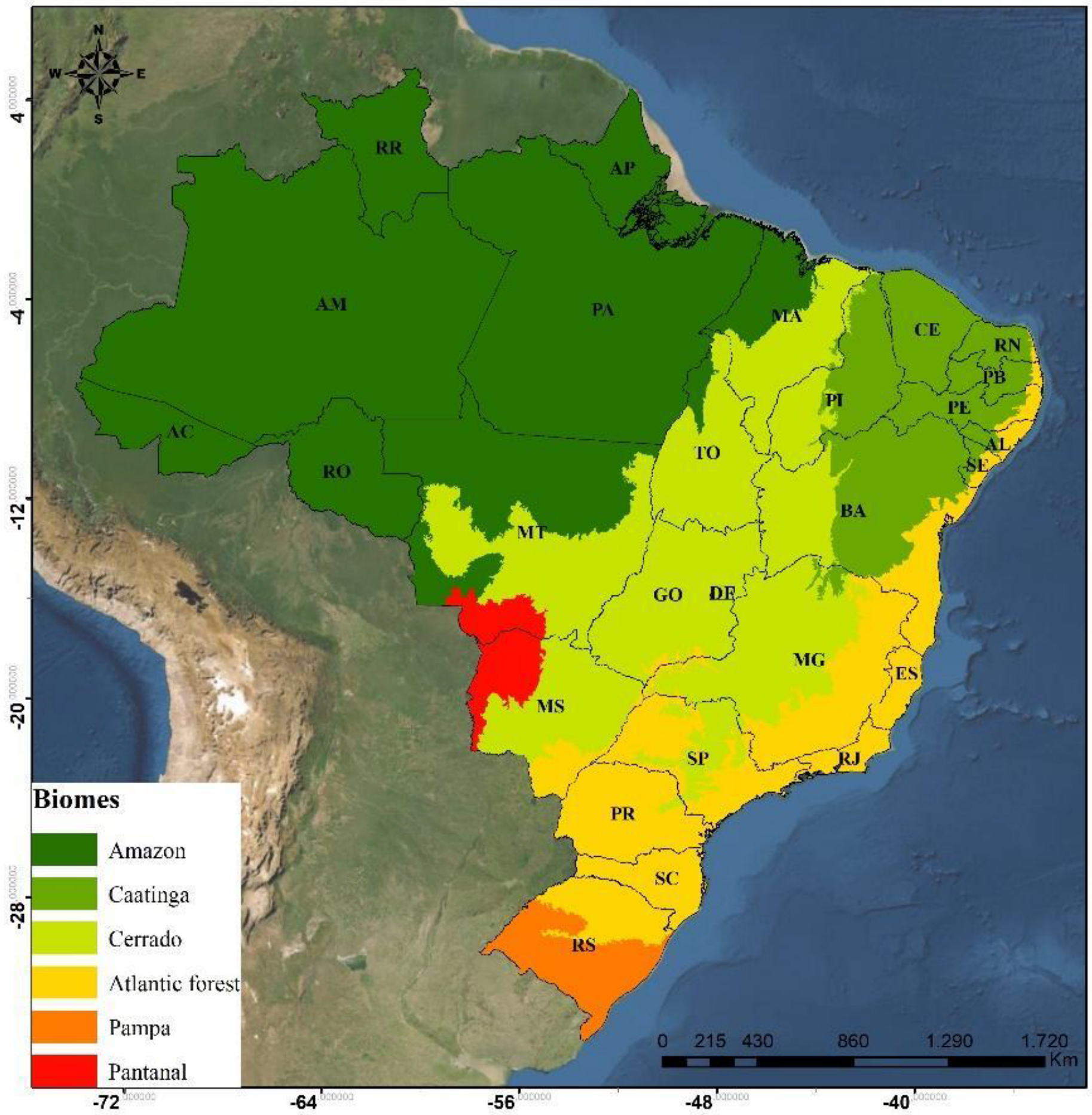

Figure 11

Spatial distribution of Brazilian biomes. 